\title{
Planning, state building, and the days after in Palestine
}

\author{
Kareem Rabie
}

\begin{abstract}
Drawn from ethnographic fieldwork and documentary research, this article examines three shifts in national-scale planning in Palestine. In the period after the Oslo accords, Palestinian planners were tasked with the responsibility to create formal structures of governance and build for a future, eventual state there. Through that process and especially after the second intifada, national planning came to focus almost exclusively on market openness, privatization, and capitalistic development as part of a state and economy building project. Increasingly since 2015, planners have attempted to re-take some kind of formal authority. This article argues that such regimes show how Palestine is increasingly crafted at the statescale as a node in wider global political economies in order to ostensibly stabilize the political situation, and in ways that have wide consequences for Palestine.
\end{abstract}

Keywords: capitalism, development, Israel, planning, Palestine, state building

It has now been more than 25 years since the Oslo declaration of principles, and in Palestine most realistic possibilities for peace and sovereignty have long since been subsumed to ongoing processes of stabilization. Despite the present situation, state-scale planning is fundamental to how Palestine is crafting its future political, economic, and social orientation toward its land, polity, Israel, and the world. Since Oslo, Palestinian planning has taken a few different approaches that map onto local political, and global economic logics, and help clarify state building and its political economic assumptions and goals.

First, in the post-Oslo period, technocratic planners presupposed a functioning state with some kind of sovereignty and contiguity. They attempted to create frameworks for regulation, distribution of housing and resources, environ- mental protection, and otherwise orient state capacity to finally serve Palestine and Palestinians. As political circumstances changed and sovereignty-or even the terms of the agreementslowly blurred at the edges, state planning was broken down to studs (Thawaba 2019; Zeid and Thawaba 2018) and international aid came to fill a gap in authority and governance (Dana 2015; Turner 2012, 2015). In the early 2000s, alongside both the erosion of government capacity and consonant with changing priorities and ideological orientations in an aid apparatus that emphasized market building and economics over service provision, this period of change had significant impact on what planning could do or mean in Palestine and for Palestinians.

National planning increasingly left particulars behind and refocused into speculative and aspirational ideological descriptions not unlike 
development reports. As state capacity eroded, the state-to-be ceded material forms of planning, not to mention authority, legal support, and development aid, to an increasingly autonomous private sector. Such planning develops ideas of state and national priority and practical support for privatization as it elaborates the ideological foundation for private governance and local planning toward market stability. That process was not without dispute, and tracing the ways that Palestinian planners within the government tried to synthesize approaches and argue for regulating authority shows how ideas of centralized government were marginalized over time.

In a non-state that does not lend itself to something like high-modernist (Scott 1998) thinking and planning, what could planning consist of? As the international scaffolding of conflict was oriented from public governance, Palestinians and international organizations worked to shape government priorities to enhance private investment and reform laws to enable it. In the peculiar West Bank market and with capacities for production or industry casualties of the long military occupation, housing and real estate are at the center of national planning as a scale of investment, a way to bring in and fix capital, and container for ideas about the future. Large development is one of the few opportunities such a state has for planning at scale.

This article draws on ethnographic research I conducted between 2009 and 2017 on largescale private housing developments, urban and national planning, and the state idea and project in the West Bank. I analyze ways the future is understood, practiced, and shaped through interventions into the built environment. Elsewhere, I argue housing acts as precedent for changing property regimes, relationships to the land, and typology (Rabie 2021). It tangibly expresses state priorities, common sense, and the forms of state themselves, in the landscape. And it exemplifies a shift from planning directly for people, politics, and land; to planning for real estate, capital, space.

I outline three planning approaches in Palestine to show how ideology and the peculiar- ities of Palestine's relationship within Israel are tangibly manifest. Next, I take planning to be a state-scale technique of governance, stabilization, and both political economic and social orientation toward future accumulation. Finally, I think through the Palestinian case toward more general geographical relationships between states and markets. Although Palestine differs from other contexts in many obvious ways, state-scale interventions such as planning-for the present and for future generations-are fundamental to what states do. The emergent state in Palestine encounters global phenomena as elsewhere, but it is a context in which the relationships between state, planning, and private development are less mediated and obscured than they might be in other situations. This discussion thus contributes to understandings of how states are responsive ideological projects materialized through fixed capital and institutions, and productive of human and state relations; in Lefebvre's terms, as a state mode of production (Brenner and Elden 2009). The case of planning in Palestine can uncover how Palestine is being imagined and formalized as a statescale set of institutions and markets in ways that are coherent within those worldwide capitalist inter-state relations that drive and order variations among states.

\section{Three phases of planning in the West Bank post-Oslo}

How is it possible to plan for a future in a context of pervasive, structural instability? In the early 1990s, when the Oslo accords proposed that an end to the occupation was within sight, Palestinian planners attempted to create the foundations for their state to come. Released in 1998, the first plan of this era outlined mechanisms and a way forward to ameliorate the historically deteriorated conditions in Palestine-geographically, environmentally, socially, in terms of governance, everything really-through methodical, technocratic planning that both assumed and worked to strengthen the foundation for sover- 
eignty and self-rule (Ministry of National Planning and International Cooperation 1998).

Soon after, the 2000s saw pervasive violence and war, a repressive Israeli closure regime, and intifada that all impacted even the conceptual possibilities for future governance and planning. As a way out and exemplified by the 2007 installation of Prime Minister Salam Fayyad, a new period of Palestinian governance emerged, indebted to and modeled on a worldwide consensus around state retreat and private governance (Haddad 2016). The promises of the Oslo process and two-state solution seemed distant, while at the same time the peace process itself was reoriented toward global governance logics, neoliberal and otherwise. One response to the question of how to approach rebuilding in the context of ongoing crisis was to orient local governance toward privatization and private development to fill in for the PA's lack of capacity. Assumptions and goals in plans to show how shifts in practice and policy are negotiated and renegotiated in light of both local possibilities and general ideas around political scales of governance.

Before Oslo created the possibility for official Palestinian territorial control, planning was a matter for Israeli state planners and military, and was oriented around logics of enforcement and done almost entirely to circumscribe Palestinian movement, land use, and growth. Since then, planning has served changing political imperatives and to formalize activity on the landscape. Today it is used to open previously unprofitable land to capital investment, but that approach was not preordained. Instead, it demonstrates the continual push and pull of political stabilization with respect to Israel, and market stabilization.

\section{8}

In the Oslo-era hopefulness of the mid- and late-1990s, a Palestinian planning movement emerged in one part of the PA. The $1998 \mathrm{Na}-$ tional Plan was its first serious attempt to in- stitute a legal, formal, comprehensive planning regime for the West Bank (and, at the time, Gaza). Palestinian planners set out to use their new authority under the PA to create a coherent system as well as a road map for formalizing Palestinians' interactions with the built environment for the future. The 1998 National Plan frames its goals in terms of the need to create a responsive framework for fixing the structural, physical, economic, housing, distribution, and environmental problems that decades of occupation have created for Palestine. Planners worried their authority in the moment could be fleeting, so they attempted to formalize important attributes like regional planning and resource use. As Palestinians gained greater sovereignty over larger parts of the West Bank and Gaza, they had to build capacity at the same time as they defined land use and provided a vision for linking and growing regional settlement. I quote from it here at length.

The planner and then Deputy Minister of Planning Samih al-Abed's preface states:

As we are at the end of the 1990s, Palestinian society is embarking on a new era. For the first time in modern history, Palestinians will be able to shape and direct the development of their future, limited to the areas under their jurisdiction. The signing of the Declaration of principles by the PLO and the Israeli Government in September 1993 and the election of the Palestinian Legislative Council in January 1996 have created a new framework for Palestinian control over the planning process and the development of the built-up environment. ... During Israeli occupation, Palestinians were not allowed to participate in any form of planning, as development was entirely controlled by the Israeli Civil Administration. Israeli withdrawal from areas under Palestinian jurisdiction and from Palestinian civil affairs after the signing of the Interim Agreement on the West Bank and the 
Gaza Strip on September 28, 1995, left no basic data and planning capacity for future development. Consequently, the PNA through the Ministry of Planning and International Co-operation (MOPIC) has had to take charge and create a physical planning system from nothing. (Ministry of National Planning and International Cooperation 1998: i)

Here is how the ministry understood its remit:

There has never, in modern times, been planned development of the built-up environment in the West Bank. . . The West Bank has been encroached and divided by external rulers without structuring in relation to economic forces or an administrative-political order. There has been no development strategy for population distribution, nor allocation of land for future expansion.... The system of built-up areas developed more or less randomly and wherever possible, scattered by manmade interference, with the topography lacking the essential inter-linking infrastructure in terms of network facilities that characterize a mature and well-developed settlement system. (Ministry of National Planning and International Cooperation 1998: 6)

The technocrats then in the Ministry of Planning argued for a robust, diligent system that would help oversee Palestine's transition to a centralized state in the following years by curbing poor planning and development. The Ministry's planners based their work on needs rather than forecasting or speculation.

Their baseline was as follows:

It is assumed that by the year 2005, the Palestinians will have full authority over the entire West Bank and Gaza Strip. Borders will be opened between Palestine and other countries and the bulk of Pal- estinian refugees will start returning to Palestine. (Ministry of National Planning and International Cooperation 1998: 13)

And,

it is presupposed that by then (East) Jerusalem will be under Palestinian sovereignty. . . it is assumed that . . . settlements will become under Palestinian authority after the year 2005. (Ministry of National Planning and International Cooperation 1998: 13)

Finally, the 1998 plan talks about universal needs:

Economic growth and development under guidance of sustainability should be allocated and distributed to achieve balanced regional development, a well-functioning utilization of resources over time, and a fair distribution of income and welfare among individuals for the benefit of all. (Ministry of National Planning and International Cooperation 1998: 10)

It is true that many of the assumptions in those plans-especially the idea that Ramallah, alBireh, and Jerusalem could be considered a single urban unit-no longer hold on account of Israeli prerogative. Moreover, the legal framework was limited when the 2003 Basic Law (Palestinian 2003 Amended Basic Law) enshrined free market capitalism as the economic system in Palestine, giving the state authority to create public companies, but omitting discussion of universal resources and income distribution in favor of localization in Local Government Units, dispersing governance downwards and reorienting national-scale practice (Rabie 2021).

\section{Post-2007 from the perspective of planners}

When I conducted the bulk of my field research in 2009-2010, planning authority was being dis- 
puted within the government as part of an interministerial process to write a new national spatial plan in the shadow of the Palestinian Reform and Development Plan (PRDP). The PRDP, the PA's 2008-2010 national planning document, is the patient zero of a new kind of approach to markets and governance in the West Bank. Critical scholars have made the links between that plan, coercive reform, and peacebuilding (Turner 2012); it was also the tip of the spear for neoliberalization, public-sector fiscal reform, privatization and development, and growth of the security sector (Hanieh 2013a; Khalidi and Samour 2011). It reoriented planning away from material, physical concerns toward the ideological and spatial arrangement of Palestinian in relation to the network of states. The PRDP was a framework and set of principles that circulated and established authority and common sense toward framing interventions to follow. It was an early attempt to formalize market building and development logics into national planning.

Out of the gap left behind after a period of immense military violence during the second intifada (2000-2005), as well as internal secu- rity suppression, there emerged a "good governance" and "privatization agenda" (Haddad 2016). By the time I conducted interviews with planners in 2010, one told me, "the private sector is in front of us, unfortunately" in terms of both tangible authority and government priority. Throughout my fieldwork, planners bemoaned the way national planning was being driven by private development concerns, and how that front-runner status also meant that real estate developers and land speculators created precedent that needed to be "planned around." Developers and their allies in government utilized the fact of "no coherence" in national plans while they themselves produced it, resulting in an incoherence that was beneficial for open market creation and protectionism. As discussions about what constituted a national plan progressed-discussions that hinged on the key differences between physical plans or descriptions of economic principle-the latter soon started to take precedence. Eventually the Ministry of Planning saw its responsibility for national planning shift to the Ministry of Finance, and more material planning authority

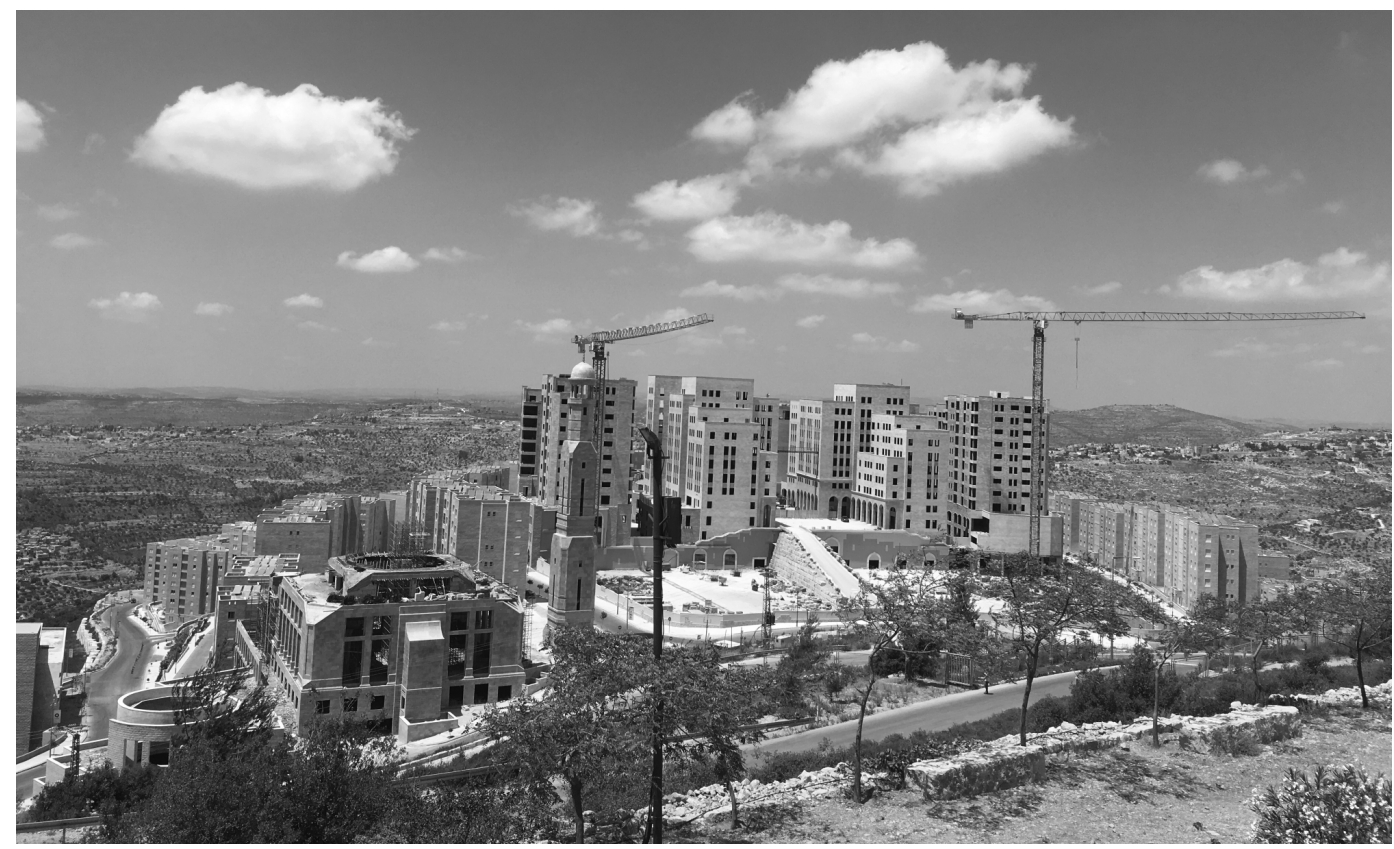

FIGURE 1. Rawabi, the largest housing development project in the West Bank and an important precedent for future development. Photo by author. 
distributed downwards through the Ministry of Local Government. ${ }^{1}$

The 1998 plan was the first government physical plan for Palestine, the first opportunity to act as state government, and it emerged in and through slowly congealing structures of authority and jurisdiction. It was, however, never formally adopted nor legally binding, even if some ministries had been using it informally. They were presented with the problem, it was revealed to me, of how, precisely, to retrofit a diligent planning agenda to a context in which less than 30 percent of West Bank (i.e., Area A and some of Area B) land was under their practical control. The plan was written within the terms of existing political agreements with Israel; as those agreements were suspended or went unimplemented, ideas about government authority eroded. As one high ranking planner put it in 2010, "the government is not controlling development even in A and B. The government is not in full control." By the time the 2007 state-building project emerged, Israel was working to roll-back and outsource its occupation while maintaining control and stability. That trend framed and structured the truncated, conditional Palestinian governing authority. It was intertwined with international development focused on privatization, deregulation, and stability for investment (Rabie 2021).

Because there were no coherent authoritative plans or precedent, no umbrella of territorial governance, and little regulation, the planners I interviewed found their jobs to no longer be forward-looking, but instead reactive ("the private sector is in front of us"). They had physical problems to overcome-there had been no spatial allocation for construction and development, and yet there was a building boom in and around Ramallah. Large housing developments began to emerge far away from cities where land was cheap, but which required tremendous government support for infrastructure and services, even before they were completed (not to mention eminent domain, lender-friendly tenant laws, and so on). Unfortunately, "we have needs in areas that are populated." They be- moaned the lack of government zoning-"protection," they called it. They wished for sensible planning that could put housing in central areas and near existing infrastructure; and treatment plants, landfills, and the like, on the peripheries. They believed they could aid political development and private investment by correctly zoning and regulating, and tendering bids from developers. In their view, ministries prioritized developers, and oriented national plans around that priority. State-scale economics took precedence over the state, and large-scale development was understood, even though it had such massive legal, social, and spatial connotations, primarily as "value added for the economy." Ironically, the state-scale retreated at the same time it was being built-up; it left a consequently large opening for a remade form of governance and priority. As market logics replaced territorial governance, planners found themselves having to contend not only with an occupation through an incoherent state form but with market pressures.

More recently, spatial planning has left national plans in favor of aspirational language. This shift in planning and governance is a familiar one in all contexts of neoliberalization or state roll-back. The difference here is that it is happening as a productive force and while a putative state is emerging. Recent national plans describe the ways planning is necessary but impossible. Their language is ideological; as they circulate, they frame and shape and the image of how Palestine moves forward. The approach was reflected in subsequent national plans and national program documents with names like "Ending the Occupation, Building a State" in 2009; "Palestine Moving Forward" and "Homestretch to Freedom" in 2010; "Establishing the State, Building Our Future" the 2011-2013 plan; and in 2014-2016 we saw "State Building to Sovereignty." Apparently, the goal has been achieved and subjects incorporated into the state, allowing the PA to move to the "next phase" with their 2017-2022 plan of "Putting Citizens First." Yet beyond the perhaps unearned optimism in their presentation, these state plans are, like all plans, productive. 


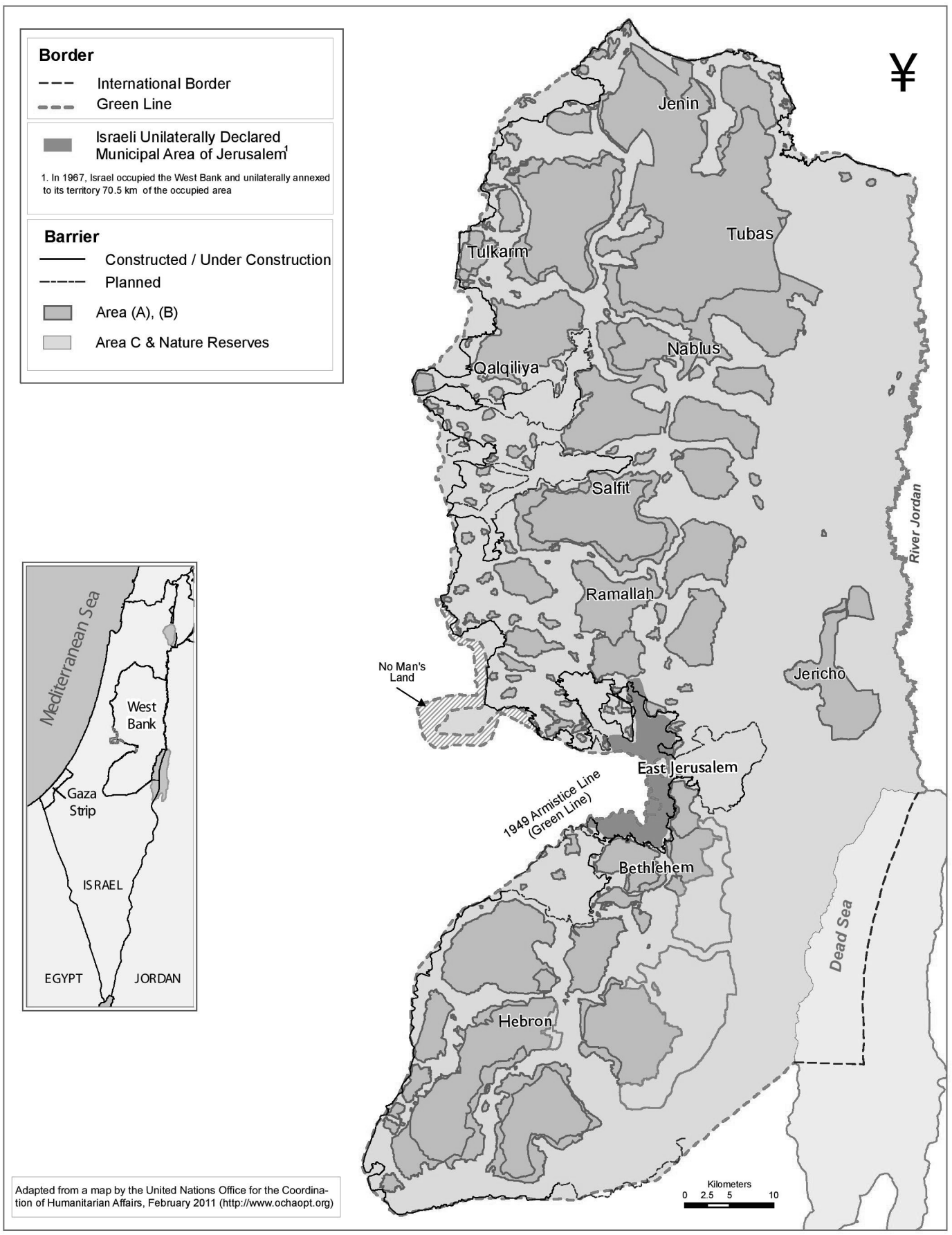

Figure 2. Areas A, B, and C, borders and barriers in the West Bank. Source: Palestinian Academic Society for the Study of International Affairs (PASSIA). 
They represent, describe, and orient government reforms, priorities, and interventions to the funders, organizations, and states who help implement them. They also propose and shape possibilities to justify aid investment and private sector responsibility. And they become the basis for the reports that follow. Through new plans, politics, laws, and national priorities are reoriented; the desire for formalization turned into a need for openness. Whatever problems previous plans sought to address were opened to market forces and profit-making intervention. Plans, even those without clear referents, are important forms of documentary evidence that accrue practical authority as they move and engage human activity (Ferguson 1994; Hull 2012). Through national planning, groups of developers and bureaucrats make their visions authoritative, sensible, and legitimate, and they incorporate people as they shift government priorities and goals toward privatization and localization.

\section{5}

In the early and mid-2010s, planners within the government told me they attempted to change this direction and fought for a spatial planning practice that could recreate a sphere for technical approaches to policy-in effect, economic and spatial regulation-as a way to order and orient the influence of the private sector. They attempted to stabilize authority and to lend coherence to a context characterized by giveaways. They wanted to bring social, spatial, economic, and political planning back to Palestine. They held a series of meetings throughout 2015 and in cooperation with the United Nations to incorporate stakeholders in the West Bank, Jerusalem, and Gaza, and released their findings and arguments later that year (National Spatial Plan 2015). It is not clear how it was taken up; the report is available on some international organizations' document depositories, but it no longer appears on the Ministry of Planning's site (and according to the Internet Archive's Wayback
Machine, its own page, http://www.nsp.pna.ps, appears to only have been accessible briefly in 2017 and 2018).

The document is a synthesis of previous iterations of planning, an attempt to establish some coherence without centralization, and to do it within contemporary logics and economic practice. It was not a call for nationalization but a diligent effort to curb haphazard planning and development. From a state perspective, and without the capacity to do large-scale physical planning, the next steps for those designated to plan are clear: how to stabilize the foundation for a future in which full sovereignty is doubtful at best? How to both orient a state and do state strategy in an already uneven global political economy that emphasizes circulation (and financialization) over production or social reproduction? And at home, how to impose rational order in a context where real estate is driving planning and development?

It is a careful attempt to take practical, responsible steps toward state-scale functioning. It seeks to have new cities integrate with existing webs of infrastructure (section 3.6); it emphasizes support for rural areas economically and through service provision; and to strengthen links between Palestinians and Palestinian places. Planners propose the need for new property and tenure law (3.11) to protect Palestinians from encroachment and, perhaps, from market pressure. They wanted to treat land nationally as Palestinian and demanded restitution from Israel for settlement land seizure and construction (3.12). They plan for new schools, new ways to enhance living standards, and in support of unionization and public health. Moreover, they planned national infrastructure, including roads, stable borders, sea and air ports, and Palestinian logistics zones (National Spatial Plan 2015).

I read this plan as an attempt to enhance national- and state-scale Palestinian politics and sovereignty. Planners were writing in a context of tension between that goal and market governance. They wanted to rebalance the relationship between public and private (6.3 and 6.4), 
while also limiting the role of the public sector. To them, that means the necessity to diversify private investment (7.7). Mostly, I understand it to be an attempt to strengthen territorial (and national) governance rather than ceding it to the abstraction of market planning (National Spatial Plan 2015). ${ }^{2}$ The quick disappearance of this plan, however, would suggest that planners were not able to redirect government priority or were further marginalized as practical authority was rolled-back within ministries.

\section{Urban and State planning more generally}

Throughout its debates and iterations, urban planning practitioners have generally understood their work as attempts to implement a kind of progressive and universal transformation-social, political, through policy, as matters of technical advancement, and so on (Fainstein 2000). Yet, as critical urbanists and planners have shown, the discipline is fundamentally situated in the social context and time of its practice. Attempts at ordering the present are necessarily forward-looking projects to combine social relations, geography, and political economy (Bou Akar 2018; Gunder 2010; Yiftachel et al. 2001).

Not only in Palestine, urban and national planning are linked in part because both are about wide scales of intervention and the problems of large-scale governance (Roy 2011; Roy and Crane 2015). Cities are matters of polity and state historically constituted. In its invocation of and approach to state-scale, planning incorporates people both directly and indirectly. In part, it attempts to engineer social relations and contexts for social reproduction. A consequence is that planning can work to reorient larger populations and territories toward uneven development as it assumes forms of capital relations between states. Planning interventions work to produce and imagine a future. And through the material facts of intervention, investment, and work (Holston 1989), plans build upon prior assumptions, iterations of planning, and the material context and capacity for future interventions. Although the planning ideology may have operated on the artificial separation between technical and social, planning is always about both (Chu and Goh 2015). What happens to planning and urban-scale intervention when the state itself is openly organized around questions of markets and capital, driven by planning that focuses not on social reproduction but on finance?

Locally, the orientation toward market logics means construction drives planning and produces "reconcentration in urban centers and intensifying development within clusters on the periphery ... the scattered islands of intense use ... did not result from planners' conception of desirable spatial patterns. ... Instead, it represented the confluence of an explosion of speculative building for profit and a surging demand for space within a context of local incentives to growth and national policy antagonistic to regulation" (Fainstein 2000: xii). More broadly, in the current worldwide political economic orderof late capitalism, financialization, aggressive marketization, neoliberalism - what happens to planning's social space when responsibilities to citizens fall out of the equation, and accumulation and growth are the primary bases for legitimacy around governance? At least in the Palestinian case, state space and plans become increasingly abstract and relational. In Palestine as in Fainstein's London and New York, "the contemporary urban built environment did not represent an uncomplicated response to demand but rather that developers both molded demand and responded to public-sector initiatives and regulations" (Fainstein 2000: xii). Through development, the state is oriented toward producing itself to meet demands for growth and accumulation; it forms around market imperatives.

Processes of orientation are distributed socially as they produce exclusion (Bou Akar 2018; Yiftachel 2001). As planning progresses toward state space, it can no longer be looked at alone through the practical relationship between modernist scale and lived experience 
(Scott 1998). Abstraction in state-scale planning presupposes people as market participants, debtors, and their needs secondary to a scale of accumulation constituting statecraft. Contemporary forms of exclusion are spatial, but they are also about class and possibilities for participation and claims on state capacity. Planning is responsive to state-scale territorial orientation primarily (Roy and Crane 2015); secondarily to matters of urban governance. As the scale and forms of exclusion grow, critics increasingly focus on the gray areas and peripheries of plans (Roy 2011; Roy and Crane 2015), and possibilities for new types of citizenship and claims (Holston 2008).

Urban planning is one such institution of realignment in Palestine, a state spatial project and strategy, as well as one of few opportunities for substantial investment. Its combination of attributes is especially generative because it is at the heart of how the state itself is emerging. Not only does planning show the limits and consequences of the Oslo process, it uncovers how Palestine's political prospects have shaped its responses to worldwide political economic shifts. Previous iterations of the peace process emphasized political and territorial stability. Embedded within ideas about market solutions to Palestine's political problems, current visions orient state building as a form of market stabilization. This form of planning is logically coherent in the current global political economy, but it maintains elements of social engineering, development trajectory, and the supposition of state power to organize land and governance (Holston 1989; Scott 1998)-even through state roll-back. Instead of looking at planning through the tension between success and failure, and consequence, these are best understood in terms of their "potential" (Günel 2019). Bou Akr has asked the key question in her study of Lebanon: "What happens when planning loses its ethical basis in socioeconomic development?" (Bou Akar 2018: 147), when the logics within which it attempts to order space and polity are increasingly abstract and relational even as they congeal into the state itself?

\section{Planning, states, and mode of production}

From the perspective of the political and economic geography of the West Bank, capitalist social relations are bound to the simultaneous production of nation and territory-they are massive phenomena of remaking, embedded in political space, representational space, and ideology and practice. But they also require formal institutions, practices of land use and development, scientific knowledge, and expertise to incorporate, remake, and manage state space and marketization. Lefebvre proposes that there is a state mode of production, a scale of organization that combines social, technical, political, and economic. "The state has presided over this integration" of cities with agriculture; "Spaces that were once unoccupied-mountains, the sea-enter into exchange, become commodities, are occupied by the enormous new industries of leisure and culture" (Brenner and Elden 2009: 212). From the outset, capital's imperatives for growth expanded outwards and necessitated something like globalization-from transport systems to colonization, to labor migration and outsourcing-but also the inter-state system for regulating trade and the movement of capital (Brenner and Elden 2009: 21).

Part of how states connect to one another is by a process of homogenization-following Lefebvre, statehood is a form of spatial violence in which states establish themselves as they make spaces of capital; stabilization and order, are primary goals for state markets, and the process does not lead to a preordained result: it is ongoing, and about "homogeneity-fragmentationhierarchization” (Brenner and Elden 2009: 212). Mode of production is a worldwide scale of economic/social organization that produces institutions, ideas, and practices, including national planning. States are economically responsive and productive forms of large-scale spatial ordering and management both locally and in relation to other such scales of market and political organization. As states erode their capacities for social services and reproduction or development among a citizenry, planning increasingly works 
at the scale of the state to arrange its relationships around capitalist imperatives. As Lefebvre puts it:

The planning of space-through spacetends to replace the other modes of planning and intervention. Social and political space today is both real and operational, both a given and an instrument, a necessity and a virtuality. It is produced, a product, but also producer and reproducer (in the maintenance of relations of domination). (Brenner and Elden 2009: 212)

In this framework, planning produces and is produced by itself, its assumptions, and its ongoing processes (in this case, market creation, uneven development, and so on). Planning is a vital practice of political/spatial arrangement within and productive of context and common sense, of combining and smoothing the contradictions between large-scale accumulation and general social life within a territory.

With a different orientation, Scott's high modernism, and its needs for uniformity and commensurability, provides a fruitful path to thinking through the links between state-scale and forms of intervention and planning. If states are processes of abstraction and mapping people in service of articulating scale, what happens when there is planning that has no high-modernist faith in its capacity but nevertheless is able to order people, infrastructure, capital, and landscapes around state-scale goals for fluidity and circulation? Planning, evacuated of expertise, nevertheless assumes itself to be the "successful ordering of the built environment" (Harvey 1985) but almost entirely through its commitment to accumulation as the mechanism to define and redefine practical relationships between state and civil society.

So, in contemporary Palestine, where planning is situated in its particular social context, the question becomes: what happens when there is little or no state capacity for a modernist approach, let alone the presupposition of the re- sponsibility for intervention at scale? What happens when scale-or fixed public capitalis only desirable insofar as it can aid market growth and accumulation (and social problems thereafter)? Planning is a set of practices and institutions produced in context and productive of what the theorist and activist Jimmy Johnson has described to me as statist sociality organized around the norm of Weber's monopoly of violence within a territory. Those normative conceptions are ongoing processes that legitimate the idea of coherent state-scale authority, even as state institutions work far beyond it.

Building and planning are predicated on their future existence; they are implied, yet material, forecasts of social and economic change. Once completed they become evidence that forecasts were correct; stories written in the future tense (Searle 2017: 2). They are also the evidentiary basis for the claims and plans and stories that follow. Through various visible iterations of the plans themselves, they circulate, accrue weight and orient politics and the nature of planning itself (Ferguson 1994; Hull 2012).

Neil Brenner (2004) argues that state institutions are fundamental to orienting the urban scale toward the geographical transformation of national states, mediating the interplay between capital investment and territorial inequalitythey are part of how uneven development works. This is done by optimizing urban economics within global circuits of capital, but it is also part of the ways state-scales are realigned around questions of growth. States and cities are mediators of uneven geographical development- "it is no longer capital that is to be molded into the (territorially integrated) geography of state space, but state space that is to be molded into the (territorially differentiated) geography of capital" (Brenner 2004: 16, italics in original).

Presently, real estate interests have outsized influence on city and state governance, and planning has become an expression of capital. A preeminent concern is value generation in this "real estate state" (Stein 2019). The unique aspect of the Palestinian case is that, unlike existing cities and states from which planning theory, 
critique, and practice emerges, the close links between territorial and urban planning, state form, and capital, are part of the emergence of the state itself. Planning is especially central and especially ripe for takeover because it is one of the only institutional or institutionally convincing ways of regularizing or holding land. Capital and value-and real estate markets-are the essence of a state project in an environment where land use is militarized and a state is trying to establish itself while also shrinking. "Planners provide a window into the practical dynamics of urban change: the way the state both uses and is used by organized capital, and the power of landlords and developers at every level of government" (Stein 2019: 6). Here, real estate concerns are enmeshed with state spatial strategy and as part of the system of land holding.

\section{Planning, common sense, and capital}

The emerging state in the West Bank is an ongoing process that exists as part of and within a political system, economy, and structure of possibility scaffolded by the "conflict" and its various "solutions." Critics have long ago identified the importance of understanding the peace process as process, infused with economic rationales and need for foreign investment, as well as goals for accumulation (Dana 2015; Haddad 2016; Hanieh 2013b; Massad 2006; Turner 2012). The case of planning is one description of how governance has met the contours of wider practice while also orienting and directing it. Planning is the arrangement of social conflict within capital, a state technique, and its assumptions about ordering social life and the built environment contain and amortize conflict in service of wider accumulation (Harvey 1985: 175).

As Adam Hanieh has shown, real estate concerns almost completely drive planning and foreign investment. They are not the sole form of development, but they are central (Hanieh 2018). The urban scale-and its large-scale real estate development-is in practice critical to state strategy. It mobilizes huge amounts of capital, concentrates it, generates it, and circulates it. Large-scale development is Palestinian led and local in many ways, but it is necessarily global insofar as "the built environment cannot be exported; capital must come to it-in amounts of increasing size, enmeshed in cross-border flows, and mediated through neoliberal regulatory change" (Hanieh 2018: 150).

Architecture, planning, and all types of spatial form follow production, as Henri Lefebvre (Brenner and Elden 2009; Lefebvre 2007) and many others have argued. Fredric Jameson (1991) put it clearly-because of its scale, architecture is intertwined with capital and state. And the incorporating and orienting qualities are profound-changing space and social relations are part of the changing ways people see themselves and common sense about humanity, work, and life. It is thus difficult not to see planning, especially as it increasingly works on the state itself, as a powerful, if messy, form of political subject-making and orientation, embedded within and productive of general ideologies and frameworks around capital accumulation.

The case of planning in Palestine is one in which space, spatial production, are a potential fix - not as a solution, but as a moment and a node of fixity, and a way to see geography through the dynamics of capital. Planning today, in the ways that it presupposes an abstract relationship to a polity, is the ideological and material work to make state space and elaborate the relationships between state and market. It is a part of the worldwide geographical organization of capitalism. As Neil Smith told us long ago (1984), uneven development is in part a global and territorial division of labor, a constant seesaw that also produces place, inter-state, and social relations.

Plans have social efficacy-they are narratives that practically orient capacity and future; they are part of the state process and the stories it tells about what it is and what it does, as it tends toward nodes of fixity in some places, and zones of non-stability in others. Planning 
is not a permanent fix, rather it is a way to see wider state-scale imperatives and arrangements in service of inter-state and generalized capital accumulation. And the process of fixing capital at a large scale in things like private urban developments also has a tremendous social role. Place-creation means incorporating subjects and creating contexts for social reproduction and common sense. Contemporary global political economy, neoliberalism and otherwise, is not about dissolving a state but reconstituting it and its relationships to subjects. Especially in a Palestinian case which did not require a Reagan or a Thatcher to push reform, smash unions, or smooth processes of financialization, Palestine is being purpose-built, planned, and oriented as a scale of economic organization.

\section{Coda: class, diaspora, and return}

Even in accounts that take Palestine to be a part of the world, too often global phenomena appear unique to Palestine; worldwide links burn up as soon as they fall out of orbit and into the Palestinian atmosphere. Planning for real estate and accumulation is a bridge between the orientation of the state vis-à-vis the network of states, and the context for social life.

Planning links actors at different scales through ideas and interventions to shape both the present and the future that might emerge. Plans are meaningful for social reproduction, place and time, and how Palestinians conceive of the future. But they are also mechanisms for exclusion-a contemporary Palestinian planning agenda that no longer seeks to craft physical space with the entire nation in mind. Indeed, it cedes that capacity to vested interests within the private sector, with the consequence of establishing a class character for inclusion in Palestine that weakens the links between the territory under Palestinian management and the nation in diaspora.

Open market ideology inflects PA practice and materializes in its plans and interventions into the landscape. Palestinians within Palestine are incorporated and tied to phenomena and goals beyond Palestine. Yet those goals are not inward looking toward the nation and diaspora but outward looking toward the network of states and markets. State-scale plans that seek to orient investment and make land profitable through an emphasis on private housing and development create a Palestine in which class stratification is increasingly a vector for limiting the possibilities for return.

In the US case, Keeanga-Yamahtta Taylor (2019) describes the dynamics of incorporation and exclusion, as a kind of "predatory inclusion" that links race, lending, ownership, urban politics, and value to the national political and general global scales. Inclusion in Taylor's sense is fundamental to Palestine's uneven incorporation into the network of states. Options for Palestinians are structured as consumer choice, and they are abstracted into the undifferentiated filling underneath the latticework of plans. Planning is a question of lived experience-planning for finance and privatization meant granting certain access to people, but only in order to generate new sales and new payment vehicles. The orientation of state and space toward relational abstraction is itself a real, material process: disinvestment and predation by public/private partnerships in the United States meant that black houses could not become homes (Taylor 2019).

Such planning is particularly generative in Palestine as plans circulate worldwide through the language of home and cultural political yearning. But they generate vehicles for exchange value at a scale that can function toward territorial and legal stability and-although this is untested-the affective qualities of cultural, personal depoliticization and stabilization. Inclusion-structured and disproportional as it is-is premised on and generative of forms of racial and class exclusion. Institutions grow around those relations, and they are instantiated through structural, political, spatial, financial, and legal change. As Palestinians are incorporated through plans or forced to sell or 
participate in new land markets, their lives and capacities are framed by wider dynamics of market participation, inclusion, and exclusion.

\section{Acknowledgments}

This piece expands on material in and research conducted for my recent book with the support of the City University of New York, the Wenner-Gren Foundation, the National Science Foundation, the Palestinian American Research Center, and the Arab Council on the Social Sciences. Many thanks to Nasser Abourahme, Mark Griffiths, and two anonymous reviewers for genuinely helpful comments.

Kareem Rabie is assistant professor of anthropology at the University of Illinois, Chicago.

E-mail:kareem@uic.edu

\section{Notes}

1. Localization did matter to people, and the story of Fayyad is complicated in ways that state-scale critiques often do not capture. When I was conducting interviews during this period, many people, especially in peripheral villages, were happy with his tenure. Roll-back did not appear to them as a dissolution but instead through small-scale projects that were one of the only times they had seen the national government present or working on their behalf.

2. These bureaucrats and technocrats were working in difficult internal and external circumstances, and without much need for recognition. They saw the potential to use the state to help Palestinians, improve their lives, and work toward stability and political sovereignty. Amid the worldwide horror of the COVID-19 crisis, there is, perhaps, potential for long-term optimism. The pandemic has clearly and obviously demonstrated specific dangers of state retreat from social reproduction and support; cabinet meetings statements by the Palestinian Ministry of Health are new sites for dispute between the current orientation and need for a "new social contract" and national capacity.

\section{References}

Bou Akar, Hiba. 2018. For the war yet to come: Planning Beirut's frontiers. Stanford: Stanford University Press.

Brenner, Neil. 2004. New state spaces: Urban governance and the rescaling of statehood. Oxford: Oxford University Press.

Brenner, Neil, and Stuart Elden. 2009. "Henri Lefebvre on state, space, territory." International Political Sociology 3 (4): 353-377.

Chu, Eric, and Kian Goh. 2015. "Editorial-global ecologies: Politics, planning, and design." Projections: The MIT Journal of Planning 11: 7-20.

Dana, Tariq. 2015. "The symbiosis between Palestinian 'Fayyadism' and Israeli 'economic peace': The political economy of capitalist peace in the context of colonisation." Conflict, Security \& Development 15 (5): 455-477.

Fainstein, Susan S. 2000. "New directions in planning theory." Urban Affairs Review 35 (4): 451-478.

Ferguson, James. 1994. The anti-politics machine: Development, depoliticization, and bureaucratic power in Lesotho. Minneapolis: University of Minnesota Press.

Gunder, Michael. 2010. "Planning as the ideology of (neoliberal) space." Planning Theory 9 (4): 298-314.

Günel, Gökçe. 2019. Spaceship in the desert: Energy, climate change, and urban design in Abu Dhabi. Experimental Futures. Durham: Duke University Press.

Haddad, Toufic. 2016. Palestine Ltd: Neoliberalism and nationalism in the occupied territory. London: I.B.Tauris.

Hanieh, Adam. 2013a. Lineages of revolt: Issues of contemporary capitalism in the Middle East. Chicago: Haymarket Books.

Hanieh, Adam. 2013b. "The Oslo illusion." Jacobin. 2013. https://www.jacobinmag.com/2013/04/ the-oslo-illusion/

Hanieh, Adam. 2018. Money, markets, and monarchies: The Gulf Cooperation Council and the political economy of the contemporary Middle East. Cambridge: Cambridge University Press. 
Harvey, David. 1985. The urbanization of capital. Oxford: Blackwell.

Harvey, David. 2006. The limits to capital. London: Verso.

Holston, James. 1989. The modernist city: An anthropological critique of Brasilia. Chicago: University of Chicago Press.

Holston, James. 2008. Insurgent citizenship: Disjunctions of democracy and modernity in Brazil. Princeton: Princeton University Press.

Hull, Matthew S. 2012. Government of paper: The materiality of bureaucracy in urban Pakistan. Berkeley: University of California Press.

Jameson, Fredric. 1991. Postmodernism, or, the cultural logic of late capitalism. Durham: Duke University Press.

Khalidi, Raja, and Sobhi Samour. 2011. "Neoliberalism as liberation: The statehood program and the remaking of the Palestinian national movement." Journal of Palestine Studies 40 (2): 6-25.

Lefebvre, Henri. 2007. The production of space. Translated by Donald Nicholson-Smith. Malden, MA: Blackwell.

Massad, Joseph Andoni. 2006. The persistence of the Palestinian question: Essays on zionism and the Palestinians. New York: Routledge.

Ministry of National Planning and International Cooperation. 1998. "The regional plan for the West Bank Governorate." Ministry of National Planning and International Cooperation.

National Spatial Plan. 2015. "Palestine 2025, Palestine 2050: State of Palestine national spatial plan." Envisioning Palestine. Ramallah, Palestine.

Palestinian 2003 Amended Basic Law. 2003. "2003 amended basic law | The Palestinian basic law." http://www.palestinianbasiclaw.org/ basic-law/2003-amended-basic-law

Rabie, Kareem. 2021. Palestine is throwing a party and the whole world is invited: Capital and state building in the West Bank. Durham: Duke University Press.

Roy, Ananya. 2011. "Urbanisms, worlding practices and the theory of planning." Planning Theory 10 (1): 6-15.
Roy, Ananya, and Emma Shaw Crane, eds. 2015. Territories of poverty: Rethinking north and south. Geographies of Justice and Social Transformation 24. Athens, Georgia: University of Georgia Press.

Scott, James C. 1998. Seeing like a state: How certain schemes to improve the human condition have failed. New Haven: Yale University Press.

Searle, Llerena Guiu. 2017. Landscapes of accumulation: Real estate and the neoliberal imagination in contemporary India. Chicago: University of Chicago Press.

Smith, Neil. 1984. Uneven development: Nature, capital, and the production of space. New York: Blackwell.

Stein, Samuel. 2019. Capital city: Gentrification and the real estate state. Jacobin Series. London: Verso.

Taylor, Keeanga-Yamahtta. 2019. Race for profit: How banks and the real estate industry undermined black homeownership. Justice, Power, and Politics. Chapel Hill: The University of North Carolina Press.

Thawaba, Salem. 2019. "Building and planning regulations under Israeli colonial power: A critical study from Palestine." Planning Perspectives 34 (1): 133-146.

Turner, Mandy. 2012. "Completing the circle: Peacebuilding as colonial practice in the occupied Palestinian territory." International Peacekeeping 19 (4): 492-507.

Turner, Mandy. 2015. "Peacebuilding as counterinsurgency in the occupied Palestinian territory." Review of International Studies 41 (1): 73-98.

Yiftachel, Oren, et al., eds. 2001. The power of planning: Spaces of control and transformation. Dordrecht, Netherlands: Kluwer Academic Publishers.

Zeid, Maali, and Salem Thawaba. 2018. "Planning under a colonial regime in Palestine: Counter planning/decolonizing the West Bank." Land Use Policy 71 (February): 11-23. 
